\title{
Genetic diversity among 24 clones of robusta coffee in Lampung based on RAPD markers
}

\author{
SRI RAMADIANA, DWI HAPSORO`, RUSDI EVIZAL, KUKUH SETIAWAN, AGUS KARYANTO, \\ YUSNITA YUSNITA \\ Department of Agronomy and Horticulture, Faculty of Agriculture, Universitas Lampung. J1. Sumantri Brojonegoro No. 1, Bandar Lampung 35145, \\ Lampung, Indonesia. Tel. +62 813-7915-5175, `email: dwi.hapsoro@fp.unila.ac.id
}

Manuscript received: 9 February 2021. Revision accepted: 10 May 2021.

\begin{abstract}
Ramadiana S, Hapsoro D, Evizal R, Setiawan K, Karyanto A, Yusnita Y. 2021. Genetic diversity among 24 clones of robusta coffee in Lampung based on RAPD markers. Biodiversitas 22: 3122-3129. This study aimed to estimate the genetic diversity among 24 clones of Robusta coffee from Lampung, Indonesia, by use of RAPD markers. The clones consisted of 18 local and 6 BP clones. These BP clones were developed from a breeding program of The Indonesian Coffee and Cocoa Research Institute. Genomic DNAs extracted from these clones were subjected to polymerase chain reaction and the amplified products were run using gel electrophoresis. Eleven random primers produced clear, reproduceable, scorable bands. Fifty four of 86 bands showed polymorphism and were used to construct a dendrogram based on UPGMA Jaccard's Similarity Coefficients. The genetic base of the population was narrow (average genetic similarity $68.4 \%$ ), ranging from $26-93 \%$. The genetic similarity of the local clones was higher than that of BP clones. The clones were clusterred into five groups. Group 1 contained one clone (BP 534), while each of Group II-V contained more than one clone. The average genetic similarity of BP 534 to each clone of Group II-V was $41 \%$. The genetic similarity of clones in Group II, III, IV, and V were $55.5 \%, 43.0 \%, 81.1 \%$, and $80.1 \%$, respectively. This research should be very useful for selecting parents in a breeding program to produce better clones of Robusta coffee.
\end{abstract}

Keywords: Coffea canephora, clones, dendrograms, Indonesia, PCR, similarity, UPGMA

\section{INTRODUCTION}

Coffee belongs to the genus Coffea, sub-genus Coffea, family Rubiaceae and grows mostly in tropical and subtropical regions (Ferreiraa et al. 2019). The Arabica coffee (C. arabica L.) and Robusta coffee (C. canephora Pierre ex A. Froehner) are the two most cultivated coffee species world-wide which account for $60 \%$ and $40 \%$ of total world coffee production, respectively (Davis et al. 2019). Compared to the Arabica coffee, the Robusta coffee has higher caffeine content, wider geographical distribution, and more resistant to nematodes (Hendre and Aggarwal 2014) and leaf rust disease (Ulubelu Cofco Abadi. 2012). Indonesia is the fourth largest coffee producer in the world after Brazil, Vietnam, and Columbia (Eleven Coffees 2021; Walton 2020) and the third largest producer of Robusta coffee (Walton 2020). Lampung Province is one of the coffee production centers in Indonesia. However, the data presented by the Directorate General of Estate Crop (2018) revealed that coffee productivity in Lampung is only $722 \mathrm{~kg} \mathrm{ha}^{-1}$, much lower than that in Brazil $\left(1,800 \mathrm{~kg} \mathrm{ha}^{-1}\right)$ (USDA 2018), the leading producer. Not only is this low productivity caused by suboptimal cultural practices but also the use of lowyielding clones. However, the introduction of high-yielding clones sometimes resulted in variable successes because of their low adaptability to Lampung agroclimatic condition. Therefore, breeding programs should take into account gene pools of local origin and their genetic diversity.
Knowing this genetic diversity is very important in order to be able to determine effective strategies to produce better clones. Since Robusta coffee is a cross-pollinating plant, crosses among genetically-distant genotypes would expectedly lead to maximum heterosis.

A pioneer study on genetic diversity of Robusta coffee was undertaken by Berthaud (1986) who identified two main diversity groups, i.e. Congolese group (from the Democratic Republic of Congo, the Central African Republic, and Cameroon) and Guinean group (from Guinea and the Ivory Coast). Montagnon et al. (1992) proposed that the Congolese group be divided into two subgroups, i.e. SG1 and SG2. Gomez et al. (2009), using 107 genotypes of Robusta coffee selected from those used by Dussert et al. (1999), identified five diversity groups across West and Central Africa, i.e. groups A (Congo and Cameroon), B (eastern-central Africa), C (western-central Africa, Cameroon, and northeastern Congo), D (Guinea and Ivory Coast), and E (Congo and Southern Cameroon).

Genetic diversity within Robusta coffee cultivated in Lampung is needed for developing a breeding strategy to produce better clones. Genetic diversity of plant genotypes could be studied on the basis of morphological (Ngugi et al. 2019), biochemical (Mahmoud and Abd EL-Fatah 2020), and molecular (Motta et al. 2014; Omingo et al. 2017; Sousa et al. 2017) markers. One of the drawbacks of using morphological and biochemical markers is that they are influenced by the environment, while molecular markers are not influenced by the environment (Bekele and 
Bekele 2014; Nadeem et al. 2018). One of such molecular markers used for the study of genetic diversity in crop plants is Random Amplified Polymorphic DNA (RAPDs). For quite many researchers, this marker is still a marker of choice because it is simple, applicable to any genomes, does not need sequence information and needs relatively small DNA quantities (Dhakshanamoorthy et al. 2015). RAPD markers have been reported to be an effective tool to detect genetic variation at DNA level in various plants such as date palm (Marsafari and Mehrabi 2013; Srivashtav et al. 2013), teak (Chaudhari et al. 2018; Chhajer et al. 2018), sugarcane (Hapsoro et al. 2015; Singth et al. 2017), tea (Islam et al. 2013; Martono and Syafarudin 2018), rice (Alam et al. 2014; Karande et al. 2017), and soybean (AlSaghir and Salam 2011; Malik et al. 2017).

Studies on genetic diversity of Robusta coffee based on RAPD markers have also been reported (Awati et al. 2018; Achar et al. 2015: Tshilenge et al. 2009; Diniz et al. 2005; Cabral et al. 2002). Still, such a study is needed on Robusta coffee grown in a particular agroclimatic condition, such as that of Lampung. Results of this study could be used as the basis of selecting parental clones for hybridization to produce better clones of Robusta coffee adaptable to Lampung agroclimatic condition. This research was conducted with aim of investigating genetic diversity of 24 clones of Robusta coffee from Lampung, Indonesia, using RAPD markers.

\section{MATERIALS AND METHODS}

\section{Plant materials}

Twenty four coffee clones were used in this study (Table 1). The tested clones consisted of 18 local and 6 BP clones. The local clones were those developed by local farmers through selection and considered to be clones of choice. The BP clones were developed from a breeding program of The Indonesian Coffee and Cocoa Research Institute (ICCRI) and have been officially released by the Indonesian Department of Agriculture. BP actually stands for Besoekisch Proefstation, the former name of the ICCRI. The BP clones were cordially provided by The Office of Industrial Crop Research (Balittri) of North Lampung, Indonesia. All the tested clones were currently cultivated by local farmers (Table 1, Figure 1). Single node cuttings of each clone were planted in a mixture of soil and compost $(1: 1 \mathrm{v} / \mathrm{v})$ contained in polybags, (one cutting per polybag), and maintained for 6-10 months in a greenhouse of the Faculty of Agriculture, the University of Lampung.

\section{Genomic DNA extraction and PCR condition}

Genomic DNA was isolated from healthy, disease-free leaves from second and third nodes from the growing tips of the coffee branches. Genomic DNA was extracted according to Diniz et al. (2005) with minor modifications using mixed alkyltrimethylammonium bromide (MATAB). The isolated genomic DNA was of high quality as indicated by the quality test where genomic DNA appeared as one band of high molecular weight in a gel electrophoresis and the value of absorbance of the DNA solution at $260 \mathrm{~nm}$ divided by that of $280 \mathrm{~nm}$ (A260/A280) was $1.8-2.0$.

The genomic DNA was subjected to polymerase chain reaction (PCR) using Eurogene thermocycler. The PCR reaction was carried out at a volume of $25 \mu 1$ in a $200 \mu 1$ microtube, $12.5 \mu \mathrm{l}$ of PCR kit (QIAGEN), $50 \mathrm{ng} / \mu \mathrm{l}$ of template DNA, and $2 \mu$ of a random primer. The PCR condition was set up as follows: one cycle of initial denaturation at $94^{\circ} \mathrm{C}$ for 3 minute followed by 30 cycles of denaturation at $94^{\circ} \mathrm{C}$ for 1 second, annealing at $37^{\circ} \mathrm{C}$ for 1 minute, and extension at $72^{\circ} \mathrm{C}$ for 2 minutes. Then the final extension was done at $72^{\circ} \mathrm{C}$ for 10 minutes. The amplified products were electrophoresed at 60 volt, 400 watt, for 2 hours in $1.2 \%(\mathrm{w} / \mathrm{w})$ agarose gel, stained in ethidium bromide solution, and then visualized in a UV transilluminator. Initially, a set of 40 primers selected from the studies of Achar et al. (2015), Gimase et al. (2014), and Kathurima et al. (2012) were prescreened for PCR optimization of genomic DNA of 24 clones of Robusta coffee (Coffea canephora Pierre ex A. Froehner). Eleven out of the 40 primers produced sharp, clear, and reproduceable bands and were used in this study (Table 2).
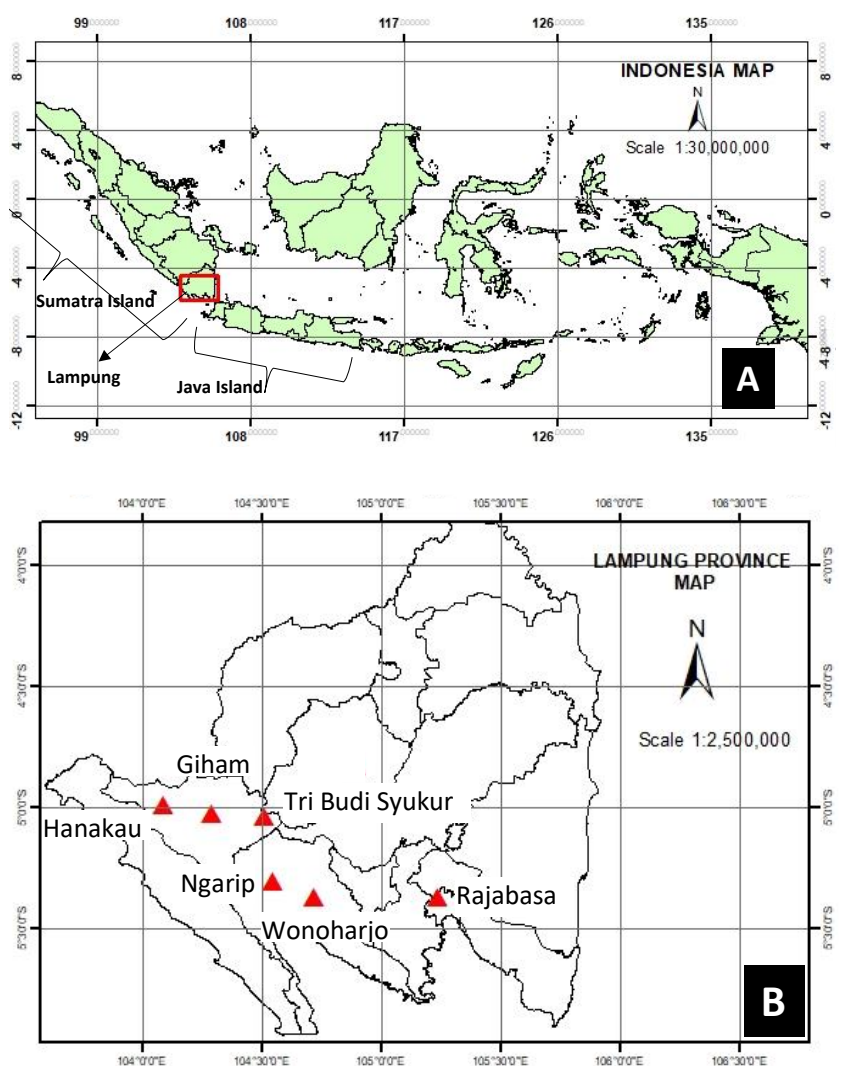

Legend

A Locations of tested clones

Figure 1. Locations of tested Robusta coffee clones used in this study. A. A map of Indonesia showing where Lampung Province, Sumatra Island, and Java Island are. B. A map of Lampung Province and locations of tested clones as indicated by triangles 
Table 1. The Coffea canephora clones used in this study and their geographical locations

\begin{tabular}{|c|c|c|c|}
\hline Clones & Village, sub district, district, province & Coordinate points & $\begin{array}{c}\text { Elevation } \\
\text { (m asl.) }\end{array}$ \\
\hline Bakir 1 & Rajabasa, Rajabasa, Bandar Lampung, Lampung & $\mathrm{N} 5^{\circ}, 22^{\prime}, 19^{\prime \prime} ; \mathrm{E} 105^{\circ}, 14^{\prime}, 15^{\prime \prime}$ & 135 \\
\hline Bakir 2 & Rajabasa, Rajabasa, Bandar Lampung, Lampung & N 5 $, 22^{\prime}, 19^{\prime \prime} ;$ E $105^{\circ}, 14^{\prime}, 15^{\prime \prime}$ & 135 \\
\hline Bakir 3 & Rajabasa, Rajabasa, Bandar Lampung, Lampung & N 5 $, 22^{\prime}, 19^{\prime \prime} ;$ E $105^{\circ}, 14^{\prime}, 15^{\prime \prime}$ & 135 \\
\hline Bakir 4 & Rajabasa, Rajabasa, Bandar Lampung, Lampung & N $5^{\circ}, 22^{\prime}, 19^{\prime \prime} ;$ E $105^{\circ}, 14^{\prime}, 15^{\prime \prime}$ & 135 \\
\hline Komari & Ngarip, Ulu Belu, Tanggamus, Lampung & N $5^{\circ}, 18^{\prime}, 28^{\prime \prime} ;$ E $104^{\circ}, 32^{\prime}, 56^{\prime \prime}$ & 874 \\
\hline Tugino & Ngarip, Ulu Belu, Tanggamus, Lampung & N $5^{\circ}, 18^{\prime}, 28^{\prime \prime} ;$ E $104^{\circ}, 32^{\prime}, 56^{\prime \prime}$ & 874 \\
\hline Wanto & Ngarip, Ulu Belu, Tanggamus, Lampung & N $5^{\circ}, 18^{\prime}, 28^{\prime \prime} ;$ E $104^{\circ}, 32^{\prime}, 56^{\prime \prime}$ & 976 \\
\hline Wardi & Ngarip, Ulu Belu, Tanggamus, Lampung & N $5^{\circ}, 18^{\prime}, 28^{\prime \prime} ;$ E $104^{\circ}, 32^{\prime}, 56^{\prime \prime}$ & 976 \\
\hline Lengkong & Tribudi Syukur, Kebun Tebu, West Lampung. Lampung & N $5^{\circ}, 02^{\prime}, 15^{\prime \prime} ;$ E $104^{\circ}, 30^{\prime}, 45^{\prime \prime}$ & 860 \\
\hline Tugu Biru & Tribudi Syukur, Kebun Tebu, West Lampung, Lampung & N $5^{\circ}, 02^{\prime}, 15^{\prime \prime} ;$ E $104^{\circ}, 30^{\prime}, 45^{\prime \prime}$ & 860 \\
\hline Rope Dale & Tribudi Syukur, Kebun Tebu, West Lampung, Lampung & N $5^{\circ}, 02^{\prime}, 15^{\prime \prime} ;$ E $104^{\circ}, 30^{\prime}, 45^{\prime \prime}$ & 860 \\
\hline Srintil & Tribudi Syukur, Kebun Tebu, West Lampung, Lampung & N $5^{\circ}, 02^{\prime}, 15^{\prime \prime} ;$ E $104^{\circ}, 30^{\prime}, 45^{\prime \prime}$ & 860 \\
\hline Rona & Tribudi Syukur, Kebun Tebu, West Lampung, Lampung & N $5^{\circ}, 02^{\prime}, 15^{\prime \prime} ;$ E $104^{\circ}, 30^{\prime}, 45^{\prime \prime}$ & 860 \\
\hline Imam 1 & Giham, Sekincau, West Lampung, Lampung & N $5^{\circ}, 01^{\prime}, 31^{\prime \prime} ;$ E $104^{\circ}, 17^{\prime}, 21^{\prime \prime}$ & 1,034 \\
\hline Garudak & Tribudi Syukur, Kebun Tebu West Lampung, Lampung & N $5^{\circ}, 02^{\prime}, 15^{\prime \prime} ;$ E $104^{\circ}, 30^{\prime}, 45^{\prime \prime}$ & 860 \\
\hline Aegawa & Hanakau, Sukau, West Lampung, Lampung & $\mathrm{N} 4^{\circ}, 59^{\prime}, 27^{\prime \prime} ; \mathrm{E} 104^{\circ}, 05^{\prime}, 12^{\prime \prime}$ & 865 \\
\hline Bodong & Wonoharjo, Sumber Rejo, Tanggamus, Lampung & N $5^{\circ}, 22^{\prime}, 07^{\prime \prime} ;$ E $104^{\circ}, 43^{\prime}, 00^{\prime \prime}$ & 461 \\
\hline Blirik & Wonoharjo, Sumber Rejo, Tanggamus, Lampung & N $5^{\circ}, 22^{\prime}, 07^{\prime \prime} ;$ E $104^{\circ}, 43^{\prime}, 00^{\prime \prime}$ & 461 \\
\hline BP 538 & These BP clones were developed from a breeding program by & & \\
\hline BP 203 & The Indonesian Coffee and Cocoa Research Institute and & & \\
\hline BP 534 & have been officially released by The Indonesian Department & & \\
\hline BP 42 & of Agriculture. & & \\
\hline \multicolumn{4}{|l|}{ BP 913} \\
\hline BP 308 & & & \\
\hline
\end{tabular}

The bands were scored for presence (1) and absence (0) for each clone. The data were organized into a matrix and subjected to cluster analysis using $\mathrm{R}$ statistical software (Venables et al. 2020). A dendrogram was constructed using similarity matrix calculation function and unweighted pair-group method using arithmetic averages (UPGMA) (Venables et al. 2020). The similarity data were also subjected to principal coordinate analysis (PCA) to generate groupings of the tested clones using GenAlEx 6.41 software (Peakall and Smouse 2012)

\section{RESULTS AND DISCUSSION}

The eleven selected primers amplified 86 DNA fragments, of which 54 were polymorphic $(62.8 \%)$ (Table 2 ). The number of bands per primer varied from 6-11 with an average of 7.8. The amplified products ranged in size from 100-2000 bp. OPE 18 generated the highest number of bands (11) ranging from 250-2000 bp, while OPN 18, OPR 1, and OPO 12 produced the lowest number of bands (6) ranging from 300-1500 bp. The polymorphism level ranged from $36-100 \%$ per primer, with an average of $64 \%$. The highest polymorphism level $(100 \%)$ was obtained by OPN 18, while the lowest $(29 \%)$ by OPL 18 . Figure 2 showed an example of a banding pattern of amplified products of PCR using the tested clones'DNA as templates and primer OPO 5.
Table 3 showed the level of genetic similarities among the 24 Robusta clones as indicated by UPGMA Jaccard's similarity coefficients. The data revealed that genetic similarity was in the range of $25.6 \%$ (BP 534 and Blirik) to 93.0\% (Bakir 1 and Lengkong), with an average of $68.4 \%$. This high percentage indicates that the clones were genetically similar to each other. In Lampung, coffee plants, including Robusta coffee, are introduced plants, which originated from Africa (Herrera and Lambot 2017). Around the year 1900, non-selected genetic materials of Robusta coffee were directly brought from Uganda and Democratic Republic of the Congo to Java and indirectly brought to Java through Europe, and then subjected to selection from 1900-1930 (Montagnon et al. 1998). Java became a primary selection center of Robusta coffee, and some of the selected genetic materials were then sent to Brazil around 1912 and sent back to Uganda and Democratic Republic of the Congo around 1916 (Montagnon et al. 1998).

Cramer (1957), based on literature on coffee researches in Indonesia, stated that Robusta coffee plants were imported from the House of Horticulture of L. Linden (Brussels) to Java in the year 1900 and distributed to several plantations in East Java. The germplasms that were coming from the center of genetic diversity of Robusta coffee were used by the ICCRI (formerly Besoekisch Proefstation) to produce superior clones. Kristian (2019) stated that Robusta coffee was introduced to Lampung from Java around 1910 by the Government of Dutch East Indies. 
Table 2. Random primers used in PCR reaction using genomic DNA of 24 clones of Coffea canephora (var. robusta) as templates

\begin{tabular}{|c|c|c|c|c|c|c|}
\hline $\begin{array}{l}\text { Name of } \\
\text { primers }\end{array}$ & Reference & $\begin{array}{c}\text { Primer sequences } \\
\left(5^{\prime}-3^{\prime}\right)\end{array}$ & $\begin{array}{l}\text { Number of } \\
\text { bands }\end{array}$ & $\begin{array}{c}\text { Number of } \\
\text { polymorphic } \\
\text { bands }\end{array}$ & $\begin{array}{c}\text { Polymorphic } \\
\text { bands (\%) }\end{array}$ & $\begin{array}{l}\text { Sizes of the } \\
\text { amplified } \\
\text { products (bp) }\end{array}$ \\
\hline OPR 1 & Achar et al. (2015) & TGCGGGTCCT & 6 & 3 & 50 & $500-1500$ \\
\hline OPN 16 & Achar et al. (2015) & AAGCGACCTG & 8 & 6 & 75 & $250-1500$ \\
\hline OPO 12 & Achar et al. (2015) & CAGTGCTGTG & 6 & 4 & 67 & $400-1500$ \\
\hline OPM 13 & Achar et al. (2015) & GGTGGTCAAG & 7 & 4 & 57 & $375-1500$ \\
\hline OPO 5 & Achar et al. (2015) & GTGTCTCAGG & 10 & 8 & 80 & $100-1750$ \\
\hline OPO 15 & Achar et al. (2015) & CCAAGCTGCC & 9 & 4 & 44 & $300-2000$ \\
\hline OPL 18 & $\begin{array}{l}\text { Achar et al. (2015); } \\
\text { Gimase et al. (2014) }\end{array}$ & ACCACCCACC & 7 & 2 & 29 & $350-1500$ \\
\hline OPN 18 & $\begin{array}{l}\text { Achar et al. (2015); } \\
\text { Gimase et al. (2014); } \\
\text { Kathurima et al. (2012) }\end{array}$ & GGTGAGGTCA & 6 & 6 & 100 & $300-1000$ \\
\hline OPG 03 & Kathurima et al. (2012) & GAGCCCTCCA & 8 & 7 & 87.5 & $375-1500$ \\
\hline OPE 18 & Kathurima et al. (2012) & GGACTGCAGA & 11 & 4 & 36 & $250-2000$ \\
\hline OPI 07 & $\begin{array}{l}\text { Kathurima et al. (2012); } \\
\text { Gimase et al. (2014) }\end{array}$ & CAGCGACAAG & 8 & 6 & 75 & $300-1250$ \\
\hline Total & & & 86 & 54 & & \\
\hline Average & & & 7.8 & 4.9 & 62.8 & \\
\hline
\end{tabular}

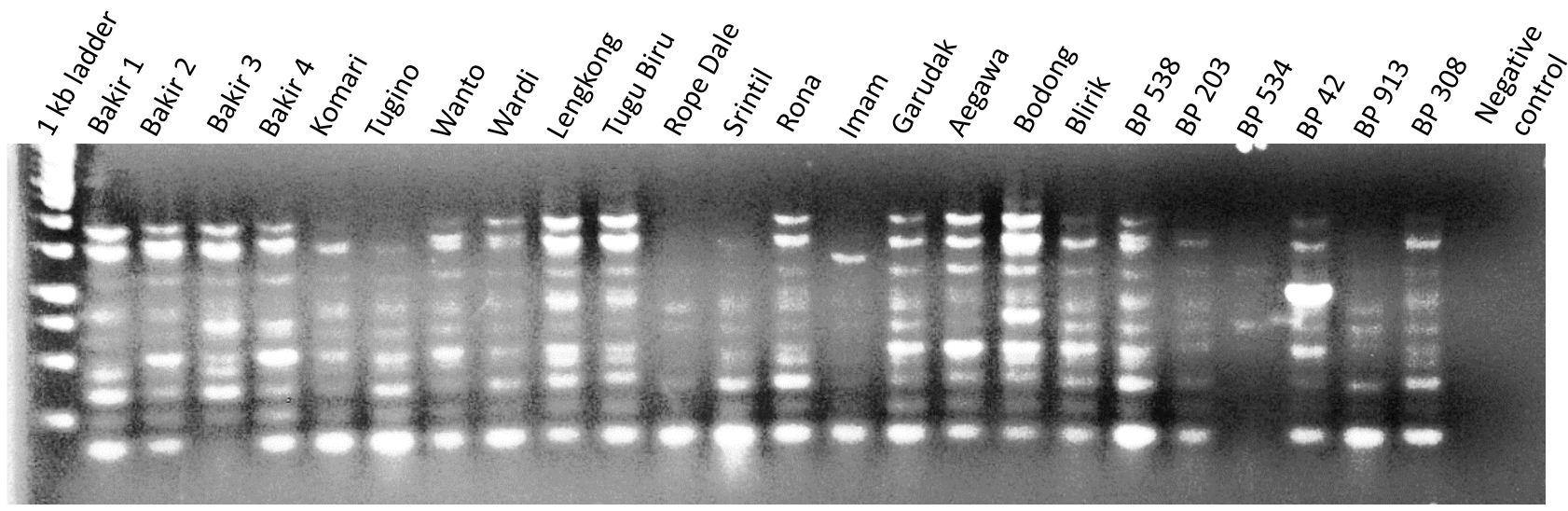

Figure 2. Banding pattern of amplified PCR products of genomic DNA from 24 Robusta coffee clones amplified with primer OPO 5

Since Java became a primary selection center of Robusta coffee from 1900-1930 (Montagnon et al. 1998), it is probable that the introduced clones in Lampung were the results of selection, so they were probably genetically narrow. The local farmers then grew them from seeds and vegetative parts and did continuous plant selection. They selected better coffee plants, took some branches (as scions) and grafted them on branches of mature plants (as rootstocks). These practices led to identification of some local superior clones of Robusta coffee. Since these selected local clones were derived from genetically limited germplasms, they understandably displayed high genetic similarity as shown in our study. Syafaruddin et al. (2014) also reported high genetic similarity $(60 \%)$ of farmerselected Robusta coffee in Bengkulu Province (also in Sumatra island). They did not mention where the Robusta coffee plants in Bengkulu came from, but Kristian (2019) stated that Robusta coffee in Bengkulu was also introduced from Java. As what happened in Lampung, the local farmers in Bengkulu did selection against seed-derived plants, then vegetatively propagated the selected ones, resulting in clones of farmer choice. This might be the reason for the high similarity.

Our study showed that BP clones showed lower genetic similarity $(58.7 \%)$ than the local ones $(73.5 \%)$. The reason might be as follows. The BP clones were developed from a breeding program using germplasm from Africa, which had wide genetic base. The local clones, on the other hand, as described before, were developed by local farmers from selected germplasm introduced from Java (Kristian 2019), which had narrow genetic base.

Some studies on genetic diversity of Robusta coffees in some regions in Africa showed lower genetic similarity, for example in Uganda $40.0 \%$ (Ngugi and Aluka 2019), Tanzania 28.8\% (Ng'homaa et al. 2017), and Congo 39.0\% (Tshilenge et al. 2009). The disparity of results between these studies and our study might be mostly due to the origin of the tested population. While these studies used populations from accessions conserved in ex-situ collections (Tshilenge et al. 2009), cultivated landraces and 
gene bank accessions (Ngugi and Aluka 2019), and cultivated and wild Robusta coffee (Ng'homaa et al. 2017), our study used population developed from selection. Because of their high diversity, some of the accessions used by these authors could be good candidates for improving Robusta coffee in Lampung.

The dendrogram constructed on the basis of UPGMA Jaccard's similarity coefficients showed that the tested clones were divided into two main clusters (Figure 3). The first cluster consisted of only one clone (BP 534), and the second cluster consisted of all the local clones (18 clones) and 5 BP clones. Based on PCA analysis, the two clusters were divided into five groups (Figure 4). Table 4 showed the average values of genetic similarity of each group, with Group IV showing the highest $(81.1 \%)$, followed by Group V (80.1\%), Group II (55.3\%), and Group III (43.0\%) (Table 4).

Figure 4 showed that the BP clones were positioned in different groups, i.e. one in Group I, one in Group II, one in Group III, and three in Group V. As for the local clones, most of them (12 clones) were positioned in Group V, two in Group II, one in Group III, and three in Group IV (Figure 4). Some BP clones were positioned in the same groups with the local clones. One possible reason was that some BP clones were introduced to local farmers in some regions of Lampung, then hybridization occurred with the local clones, leading to new local ones. Being alone in Group I, clone BP 534 shared small portion of its genetic composition with each member of other groups as indicated by the relatively small genetic similarity (41\%) with clones in the other groups (Table 3, Figure 3).

The PCA analysis also revealed no location-specific groupings of the tested clones. Some clones cultivated in the same locations were clustered in different groups. For example, clones Bakir 1, Bakir 2, Bakir 3 and Bakir 4 were cultivated in the same location (Rajabasa), but they were positioned in different groups. One group could also consist of clones of different locations. For example, each of Group II and Group III contained clones cultivated in different locations.

Table 4. Clustering of the tested Robusta coffee clones from Lampung into groups presented on the basis of PCA analysis. The average genetic similarity among clones in each group is presented

\begin{tabular}{llllll}
\hline Group I & Group II & Group III & Group IV & \multicolumn{2}{c}{ Group V } \\
\hline BP 534 & BP 913 & Bakir 3 & Wanto & BP 308 & Tugu Biru \\
& Blirik & BP 203 & Bakir 4 & BP 42 & Komari \\
& Imam 1 & & Bakir 2 & Srintil & Wardi \\
& & & & Rope Dale & BP 538 \\
& & & & Tugino & Bodong \\
& & & & Garudak & Lengkong \\
& & & & Rona & Bakir 1 \\
& & & Aegawa & \\
- & $55.3 \%$ & $43.0 \%$ & $81.1 \%$ & \multicolumn{2}{c}{$80.1 \%$} \\
& & Genetic similarity & & \\
\hline
\end{tabular}

Table 3. UPGMA Jaccard's Similarity Coefficients generated from RAPD data of 24 clones of Coffea canephora from Lampung, Indonesian

\begin{tabular}{|c|c|c|c|c|c|c|c|c|c|c|c|c|c|c|c|c|c|c|c|c|c|c|c|c|}
\hline & 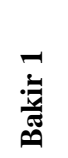 & 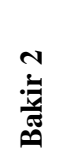 & 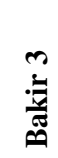 & 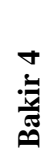 & 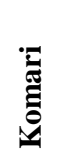 & 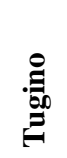 & 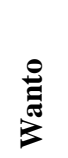 & 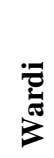 & 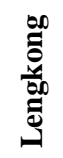 & 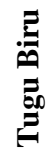 & 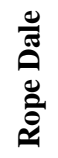 & 를 & 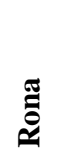 & ఏ్ & كِّ & 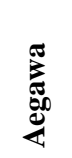 & 弟 & 凅 & $\begin{array}{l}\infty \\
\text { in } \\
n\end{array}$ & 气̂ & $\begin{array}{l}\text { జे } \\
\text { in } \\
\text { n }\end{array}$ & $\begin{array}{l}\stackrel{N}{\sim} \\
\stackrel{0}{0}\end{array}$ & $\begin{array}{l}a \\
a \\
a\end{array}$ & 官 \\
\hline Bakir 1 & 1 & & & & & & & & & & & & & & & & & & & & & & & \\
\hline Bakir 2 & 0.818 & & & & & & & & & & & & & & & & & & & & & & & \\
\hline Bakir 3 & 0.683 & 30.59 & & & & & & & & & & & & & & & & & & & & & & \\
\hline Bakir 4 & 0.733 & 0.76 & 70.6 & & & & & & & & & & & & & & & & & & & & & \\
\hline Komari & 0.8 & 0.75 & 60.6 & 0.67 & & & & & & & & & & & & & & & & & & & & \\
\hline Tugino & 0.73 & 0.69 & 60.6 & 0.68 & 0.88 & & & & & & & & & & & & & & & & & & & \\
\hline Wanto & 0.778 & 0.81 & 40.6 & 0.85 & 0.71 & 70.69 & & & & & & & & & & & & & & & & & & \\
\hline Wardi & 0.84 & 0.83 & 70.66 & 0.71 & 0.81 & 80.75 & 0.756 & & & & & & & & & & & & & & & & & \\
\hline Lengkong & 0.93 & 0.8 & $0.6^{\circ}$ & 0.71 & 0.86 & 40.8 & 0.761 & 0.8 & & & & & & & & & & & & & & & & \\
\hline Tugu Biru & 0.88 & 60.8 & $0.6^{\prime}$ & 70.71 & $0.90^{\prime}$ & 70.8 & 0.761 & 10.8 & 20.90 & & & & & & & & & & & & & & & \\
\hline Rope Dale & $0.81 \&$ & 0.73 & 30.5 & 0.65 & 0.83 & 70.77 & 0.696 & 50.8 & 0.84 & 0.84 & & & & & & & & & & & & & & \\
\hline Srintil & 0.773 & 0.72 & 70.5 & 0.68 & 0.79 & 10.81 & 0.767 & 70.7 & 0.83 & 0.79 & 0.85 & & & & & & & & & & & & & \\
\hline Imam 1 & 0.58 & 0.5 & 0.38 & 0.45 & 0.59 & 50.57 & 0.5 & 0.6 & 0.64 & 0.60 & 0.69 & 20.68 & 0.61 & 1 & & & & & & & & & & \\
\hline Garudak & 0.795 & 0.79 & 10.6 & 0.70 & 0.81 & 40.79 & 0.711 & 10.8 & 10.86 & 0.81 & 0.75 & 0.79 & 0.833 & 0.58 & & & & & & & & & & \\
\hline Aegawa & 0.78 & 70.78 & 30.6 & 0.70 & 0.88 & 60.82 & 0.745 & 50.8 & 0.84 & 0.88 & 0.78 & 30.78 & 0.822 & 0.55 & 60.8 & 1 & & & & & & & & \\
\hline Bodong & 0.867 & 70.78 & 30.6 & 0.73 & 0.80 & 40.78 & 0.783 & 30.8 & 40.88 & 0.88 & 0.74 & 50.78 & 0.822 & 0.59 & 10.76 & 10.87 & 1 & & & & & & & \\
\hline Blirik & 0.61 & 0.53 & 30.4 & 0.48 & 0.62 & 80.60 & 0.568 & 30.6 & 70.67 & 0.63 & 0.60 & 50.63 & 0.643 & 0.62 & 0.65 & 90.622 & 20.62 & & & & & & & \\
\hline BP 538 & $0.90^{\circ}$ & 70.81 & 80.6 & 0.73 & 0.8 & 0.73 & 0.778 & 30.88 & 30.88 & 0.84 & 0.81 & 30.77 & 0.778 & 0.61 & 90.75 & 60.787 & 70.90 & 0.65 & & & & & & \\
\hline BP 203 & 0.622 & 0.73 & 20.4 & 30.64 & 0.63 & 60.65 & 0.614 & +0.6 & +0.60 & 0.64 & 0.65 & 0.64 & 0.614 & 0.47 & 50.59 & 10.667 & 70.66 & 0.37 & 30.6 & & & & & \\
\hline BP 534 & 0.395 & 0.41 & 50.3 & 0.4 & 0.40 & 50.41 & 0.415 & 50.4 & +0.41 & 0.41 & 0.45 & 0.47 & 0.381 & 0.39 & 40.42 & 50.409 & 90.44 & 0.25 & 50.46 & 0.4 & & & & \\
\hline BP 42 & 0.721 & 0.67 & 40.6 & 0.66 & 0.78 & 0.75 & 0.674 & 40.7 & 0.74 & 0.78 & 0.71 & 40.75 & 0.846 & 0.62 & 20.69 & 0.685 & 90.76 & 0.57 & 0.7 & 0.5 & 0.41 & & & \\
\hline BP 913 & 0.548 & 0.53 & 70.4 & 0.56 & 0.6 & 0.61 & 0.5 & 0.5 & 60.57 & 0.57 & 0.57 & 50.61 & 0.615 & 0.59 & 40.59 & 0.523 & 30.55 & 0.5 & 0.5 & 0.5 & 0.43 & 0.68 & & \\
\hline BP 308 & 0.75 & 50.66 & 70.65 & 0.65 & 0.73 & $20.66^{\prime}$ & 0.667 & 70.6 & 0.73 & 073 & 0.66 & 70.7 & 0.75 & 0.56 & 80.76 & 90.64 & 40.72 & 0.56 & 0.7 & 0.5 & 0.43 & 0.78 & 0.67 & \\
\hline
\end{tabular}


UPGMA

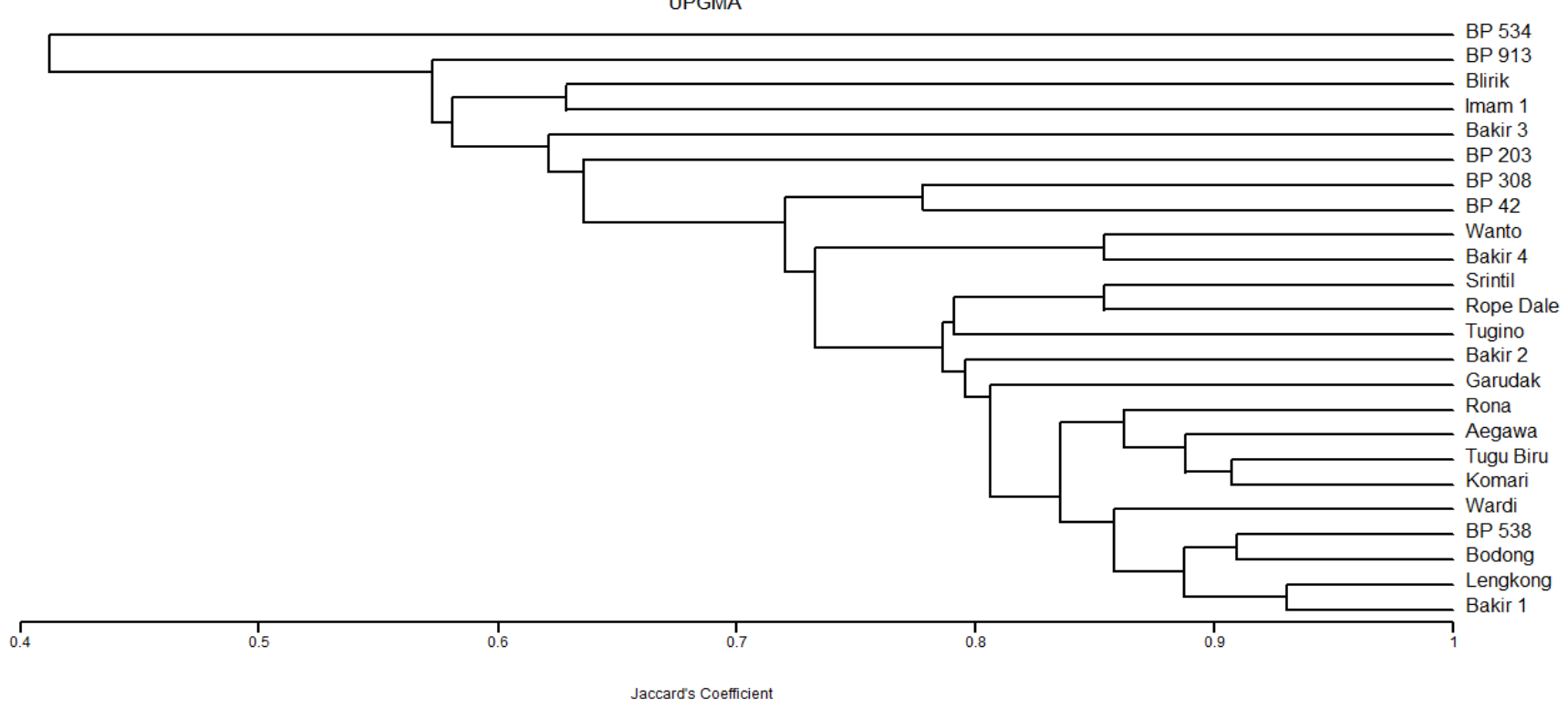

Figure 3. A dendrogram generated using UPGMA cluster analysis based on 11 RAPD markers on 24 clones of Robusta coffee grown in Lampung, Indonesia

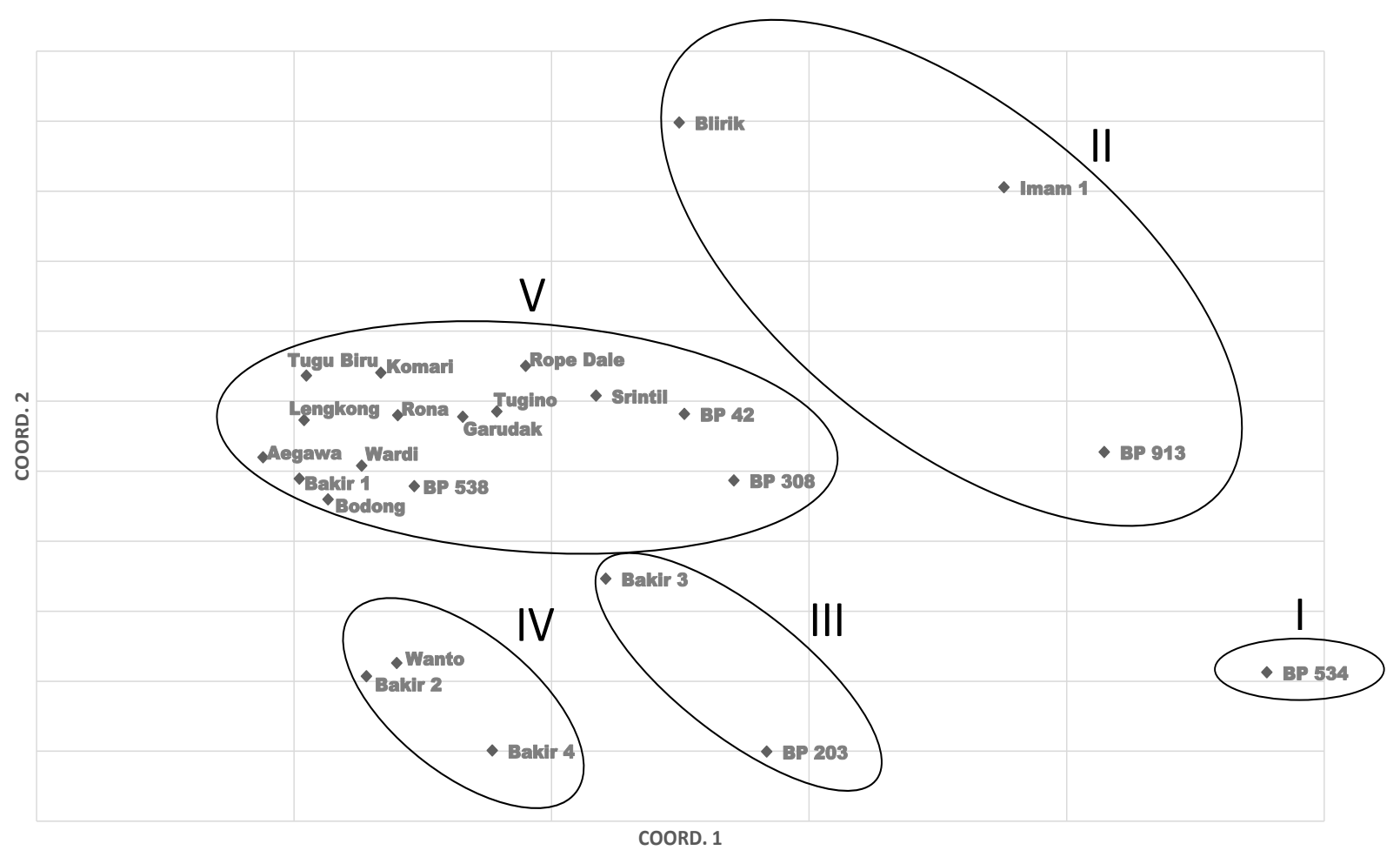

Figure 4. Estimated grouping based on principal coordinate analysis (PCA) of 24 Robusta coffee clones grown in Lampung genotyped with 11 RAPD markers.

This research is very important for designing a breeding program of Robusta coffee for adaptability to Lampung agroclimatic condition and other important traits. Firstly, the dendrogram showed that the genetic base of Robusta coffee in Lampung is narrow and could limit progress in variety development. Therefore, introduction of Robusta coffee genotypes from centers of genetic diversity is necessary to widen the genetic base. Secondly, both the tested local and BP clones were of farmers' choice. Tugino and Wanto, for example, were local clones won a coffee contest (2015) in Indonesia held by the ICCRI, coming as the best and the second-best, respectively. All of the tested 
clones could potentially complement to each other through hybridization to result in new, better clones. From genetic standpoints, much better clones could result from hybridization of progenitors of low genetic similarity, by taking advantage of heterosis. Based on the dendrogram (Figure 3), PCA (Figure 4), and data on Table 4, BP 534 would be a good candidate as a parent to be crossed with each of the other tested clones because of its quite low genetic similarity with, or quite high genetic distance from other tested clones. BP 534 was reported to be highyielding, have good taste, and show wide adaptability (Hulupi 2016). The clones which clustered in Group II and Group III would be potentially good parents for hybridization because they have relatively low genetic similarity to each other (43.0-55.3\%)(Table 4, Figure 4). In general, the clones from different groups would potentially become good parents because they have quite low genetic similarity. Crossing such clones could lead to exploitation of heterosis that could possibly lead to the development of superior clones.

In conclusion, clones of Robusta coffee cultivated by Lampung local farmers had narrow genetic base with average genetic similarity of $68.4 \%$. The local clones had higher similarity $(73.5 \%)$ than BP clones $(58.7 \%)$, which were officially released by the Government of Indonesia. The tested clones were clustered into two groups, one of which consisted of only one clone (BP 534). Therefore, BP 534 would be good as a parent to be crossed with the clones derived from the other groups because of their quite high genetic distance. However, because of the narrow genetic base of Robusta coffee from Lampung, it is necessary to introduce genetic materials from outside Indonesia to produce better clones. As far as we know, this is the first report on genetic diversity of Robusta coffee grown in Lampung, making it important for a breeding program for the development of better clones of Robusta coffee for the Lampung Province. As far as international coffee community is concerned, this report might be important in order to take advantage of the tested clones and to help increase genetic variability of Robusta coffee in Lampung by introducing genotypes from outside Indonesia.

\section{ACKNOWLEDGEMENTS}

We would like to acknowledge the University of Lampung, Indonesia, for providing financial support for this research, granted to Prof Yusnita through Professor Grant Program. We also would like to thank The Integrated Laboratory and Center of Technological Innovation, The University of Lampung, for facilitating molecular analysis. Our appreciation also goes to Hayane Adeline Warganegara, for her help in DNA isolation and Wawan Abdullah Setiawan, for his help in PCR works.

\section{REFERENCES}

Achar AMD, Danial G, Awati M, Udayakumar M, Prasad TG. 2015 Study of genetic diversity of Coffea canephora Pierre ex A. Froehner successions by RAPD markers. Intl J Plant Breed Genet 9 (3): 95 105. DOI: 10.3923/ijpbg.2015.95.105.

Alam MS, Begum SN, Gupta R, Islam SN. 2014. Genetic diversity analysis of rice (Oryza sativa L.) landraces through RAPD markers. Intl J Agric Res Innov Technol 4 (1): 77-87. DOI: 10.3329/ijarit.v4i1.21099.

Al-Saghir MG, Salam ASGA, 2011. Genetic diversity of North American soybean (Glycine max L.) cultivars as revealed by RAPD markers. J Plant Sci 6: 36-42. DOI: 10.3923/jps.2011.36.42.

Awati MG, Tambat BS, D'souza GF, Venkataramanan D, Kumar MU, Anand CG, Raghuramulu, Y. 2018. Assessing genetic diversity using RAPD molecular markers in Coffea canephora Pierre ex. Froehner (Robusta coffee): A step towards crop improvement. Intl J Curr Microbiol Appl Sci 7 (12): 1704-1714. DOI: 10.20546/ijcmas.2018.712.198.

Bekele A, Bekele E. 2014. Overview: Morphological and molecular markers role in crop improvement programs. Intl J Curr Res Life Sci 3 (3): 35-42.

Berthaud J. 1986. Les Ressources Génétiques Pour L'amélioration des Caféiers Africains Diploïdes. Collection Travaux et documents edn., Montpellier.

Cabral TAT, Sakiyama NS, Zambolim L, Pereira AA, Barros EG, Sakiyama CCH. 2002. Reproducibility of the RAPD marker and its efficiency in coffee tree genotype grouping analysis. Crop Breed Appl Biotechnol 2 (1): 121-129. DOI: 10.12702/1984-7033.v02n01a16.

Chaudhari C, Jha SK, Dhaka RK, Parekh V, Sankanur MS, Prajapat P, Thakur S. 2018. Genetic diversity analysis of teak in South Gujarat by RAPD marker. Intl J Chem Stud 6 (6): 260-267.

Chhajer S, Jukanti AK, Bhatt RK, Kalia RK. 2018. Genetic diversity studies in endangered desert teak [Tecomella undulata (Sm) Seem] using arbitrary (RAPD), semi-arbitrary (ISSR) and sequence-based (nuclear rDNA) markers. Trees 32 (4): 1083-1101. DOI: 10.1007/s00468-018-1697-9.

Cramer PJS. 1957. A Review of Literature of Coffee Research in Indonesia. In: Wellman FL. (ed.). SIC Editorial. Inter American Institute of Agriculture, San José, Costa Rica.

Davis AP, Chadburn H, Moat J, O'Sullivan R, Hargreaves S, Lughadha EN. 2019. High extinction risk for wild coffee species and implications for coffee sector sustainability. Sci Adv 5: 1-9. DOI: 10.1126/sciadv.aav3473.

Dhakshanamoorthy D, Selvaraj R, Chidambaram A. 2015. Utility of RAPD marker for genetic diversity analysis in gamma rays and ethyl methane sulphonate (EMS)-treated Jatropha curcas plants. C R Biologies 388: 75-82. DOI: 10.1016/j.crvi.2014.12.002.

Diniz LEC, Ruas CD, Carvalho VD, Torres FM, Ruas EA, Santos MD, Sera T, Ruas PM. 2005 Genetic diversity among forty coffee varieties assessed by RAPD markers associated with restriction digestion. Brazilian Archiv Biol Technol 48 (4): 511-521. DOI: 10.1590/S151689132005000500002 .

Directorate General of Estate Crop. 2018. Tree Crop Estate Statistics of Indonesia. 2017-2019. Coffee. Directorate General of Estate Crop, Jakarta. [Indonesian]

Eleven Coffees. 2021. 25 Top Coffee-Producing Countries in 2020. https://elevencoffees.com/top-coffee-producing-countries/ Accessed 1 February 2021.

Ferreiraa T, Shulerb J, Guimarãesb R, Farah A. 2019. Introduction to coffee plant and genetics, In: Farah A (ed.). Coffee: Production, quality and chemistry. The Royal Society of Chemistry, London.

Gimase JM, Thagana WM, Kirubi DT, Gichuru EK, Gichimu BM. 2014. Genetic characterization of Arabusta coffee hybrids and their parental genotypes using molecular markers. Plant Cell Biotechnol Mol Biol $15(1-2): 31-42$.

Gomez C, Dussert S, Hamon P, Hamon S, De Kochko A, Poncet V. 2009. Current genetic differentiation of Coffea canephora Pierre ex A. Froehn in the Guineo-Congolian African zone: Cumulative impact of ancient climatic changes and recent human activities. BMC Evol Biol 9: 167. DOI: 10.1186/1471- 2148-9-167.

Hapsoro D, Warganegara HA, Utomo SD, Sriyani N, Yusnita. 2015. Genetic diversity among sugarcane (Saccharum officinarum L.) genotypes as shown by randomly amplified polymorphic DNA (RAPD). Agrivita 37 (2): 247-257. DOI: 10.17503/agrivita.v37i3.499.

Hendre PS, Aggarwal RK. 2014. Development of genic and genomic SSR markers of Robusta coffee (Coffea canephora Pierre ex A. Froehner). PLoS One 9 (12): e113661. DOI: 10.1371/journal.pone.0113661. 
Herrera JC, Lambot C. 2017. The Coffee Tree: Genetic Diversity and Origin. In: Folmer B (ed.). The Craft and Science of Coffee. Academic Press, Cambridge.

Hulupi R. 2016. Bahan Tanam Kopi. In Teguh Wahyudi, Pujiyanto, dan Misnawi (Eds.) Kopi: Sejarah, Botani, Proses Produksi, Pengolahan, Produksi Hilir, dan Sistem Kemitraan. Gajah Mada University Press, Yogyakarta. [Indonesian]

Islam MN, Boonerjee S, Hoque MI, Sarker RH. 2013. Genetic diversity analysis of eighteen tea (Camellia sinensis L.) clones of Bangladesh through RAPD. Plant Tissue Culture Biotechnol 23 (2): 189-199. DOI: $10.3329 /$ ptcb.v23i2.17520.

Karande PT, Nandeshwar BC, Kokane AD, Chavhan RL, Dethe AM. 2017. Assessment of genetic diversity using RAPD marker among different varieties of rice (Oryza sativa). Intl J Trop Agric 35 (3): 509-516.

Kathurima CW, Kenji GM, Muhoho SM, Boulanger R, Gichimu BM, Gichuru EK. 2012. Genetic diversity among commercial coffee varieties, advanced selections and museum collections in Kenya using molecular markers. Intl J Biodiver Conserv 4 (2): 39-46. DOI: $10.5897 / \mathrm{IJBC} 11.231$

Kristian Y. 2019. Politik Ekonomi Belanda terhadap Lampung pada Tahun 1800-1942. Uwais Inspirasi Indonesia, Ponorogo. [Indonesian]

Mahmoud AF, Abd EL-Fatah BES. 2020. Genetic diversity studies and identification of molecular and biochemical markers associated with Fusarium wilt resistance in cultivated Faba bean (Vicia faba). Plant Pathol J 36 (1): 11-28. DOI: 10.5423/PPJ.OA.04.2019.0119

Malik MFA, Tariq K, Qureshi AS, Khan MR, Ashraf M, Naz G, Ali A. 2017. Analysis of genetic diversity of soybean germplasm from five different origins using RAPD markers. Acta Horticulturae $\begin{array}{lllll}\text { Scandinavica } & 67 & \text { (2): } & 148-154 & \text { DOI: }\end{array}$ 10.1080/09064710.2016.1236213.

Marsafari M, Mehrabi AA. 2013. Molecular identification and genetic diversity of Iranian date palm (Phoenix dactylifera $\mathrm{L}$.) cultivars using ISSR and RAPD markers. Austr J Crop Sci 7 (8): 1160-1166.

Martono B, Syafarudin. 2018. Genetic variability of 21 tea genotypes [Camellia sinensis (L.) O. Kuntze] based on RAPD markers. Jurnal Tanaman Industri dan Penyegar 5 (2): 77-86. DOI: 10.21082/jtidp.v5n2.2018.p77-86. [Indonesian]

Montagnon C, Leroy T, Eskes AB. 1998. Amélioration variétale de Coffea canephora. II. Les programmes de sélection et leurs résultats. Plantations, recherche, developpement. [French]

Montagnon C, Leroy T, Yapo A. 1992. Genotypic and phenotypic diversity of some coffee groups (Coffea canephora Pierre) in the collections - consequences on their use inbreeding. Café Cacao Thé 36: $187-198$

Motta LB, Cristina T, Soares B, Amélia M, Ferrão G, Caixeta ET, Lorenzoni RM, Dias J, Neto DS, Pós-graduação P. De Vegetal P, Federal U. 2014. Molecular characterization of Arabica and Conilon coffee plant genotypes by SSR and ISSR markers. Brazilian Arch Biol Technol 57: 728-735. DOI: 10.1590/S1516-8913201402071

Nadeem MA, Nawaz MA, Shahid MQ, Doğan Y, Comertpay G, Yıldız M, Hatipoğlu R, Ahmad F, Alsaleh A, Labhane N, Özkan H, Chung G,
Baloch FS. 2018. DNA molecular markers in plant breeding: Current status and recent advancements in genomic selection and genome editing. Biotechnol Biotechnol Equip 32 (2): 261-285. DOI: 10.1080/13102818.2017.1400401

Ng'homaa NM, Kusolwab PM, Mamiroc DP, Kilambod DL, Massawee DP. 2017. Microsatellite (SSR) analysis on genetic diversity of (Coffea canephora) germplasm in Kagera region, Tanzania. Intl J Sci Basic Appl Res 36 (2): 218-233.

Ngugi K, Aluka P. 2019. Genetic and phenotypic diversity of Robusta coffee (Coffea canephora L.). Caffeinated Cocoa Based Beverages 8: 89-130. DOI: 10.1016/B978-0-12-815864-7.00003-9.

Omingo DO, Omondi CO, Cheserek J, Runo S, Okun D. 2017. Diversity analysis of selected coffee genotypes using microsatellites and random amplified polymorphic DNA in Kenya. Intl J Biotechnol Food Sci 5 (1): 1-9.

Peakall R, Smouse PE. 2012.GenAIEx 6.5:Genetic analysis in Excel. Population genetic software for teaching and research-an update. Bioinformatics28(19):2537-539.DOI: 10.1093/bioinformatics/bts460.

Singth P, Sujeet PS, Tiwari AK, Sharma BL. 2017. Genetic diversity of sugarcane hybrid cultivars by RAPD markers. 3 Biotech 7 (3): 1-5. DOI: 10.1007/s13205-017-0855-x.

Sousa TV, Caixeta ET, Alkimim ER, de Oliveira ACB, Pereira AA, Zambolim L, Sakiyama NS. 2017. Molecular markers useful to discriminate Coffea arabica cultivars with high genetic similarity. Euphytica 213: 1-15. DOI: 10.1007/s10681-017-1865-9.

Srivashtava VS, Kapadia CV, Mahatma MK, Jha SK, Jha S, Ahmed T. 2013. Genetic diversity of date palm (Phoenix dactylifera L.) in the Kutch region of India using RAPD and ISSR markers. Emir J Food Agric 25 (11): 798-806. DOI: 10.9755/ejfa.v25i10.xxxxxxxx.

Syafaruddin S, Randriani E,. Dani D, Sulistyorini I, Pabendon MB. 2014. Genetic variability of 15 robusta coffee genotypes selected by farmer based on SSRs markers. Jurnal Tanaman Industri dan Penyegar 1 (2): 87-94. DOI: 10.21082/jtidp.v1n2.2014.p87-94.

Tshilenge P, Nkongolo KK, Mehes M, Kalonji A. 2009. Genetic variation in Coffea canephora L. (Var. Robusta) accessions from the founder gene pool evaluated with ISSR and RAPD. Afr J Biotechnol 8 (3): 380-390.

Ulubelu Cofco Abadi. 2012. Coffee History in Indonesia. http://www.ulubelu.com/articleCoffeeHistInInd.html. Accessed 1 February 2021

USDA. 2018. Coffee: World markets and trade. USDA foreign agricultural service, December 2018. http://www.fas.usda.gov/data/ coffee-world-markets-and-trade. Accessed 1 February 2021

Venables WN, Smith DM, The R Core Team. 2020. An Introduction to R. Notes on R: A Programming Environment for Data Analysis and Graphics. Version 4.0.3 (2020-10-10).

Walton J. 2020. The 5 Countries That Produce the Most Coffee. The Investopedia Express Podcast. https://www.investopedia.com/ articles/investing/091415/5-countries-produce-most-coffee.asp. Accessed 1 February 2021. 